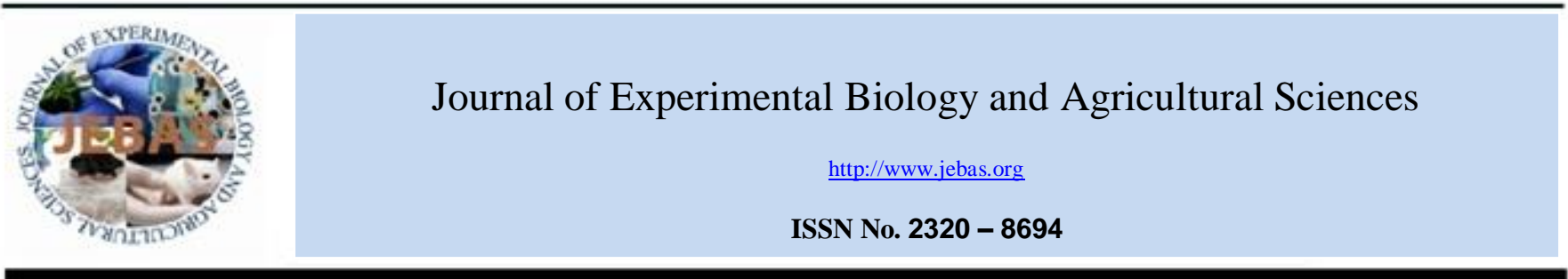

\title{
IN VITRO REGENERATION AND TRANSFORMATION OF APPLE (Malus domestica Borkh.) ROOTSTOCK MALLING 7 USING RICE CHITINASE GENE
}

\author{
SHARMA Parul ${ }^{*}$, MODGIL Manju, SHARMA Rajnish
}

Department of Biotechnology, Dr YS Parmar University of Horticulture \& Forestry, Nauni, Solan (HP) 173230 INDIA

Received - April 16, 2017; Revision - June 28, 2017; Accepted - October 04, 2017

Available Online - October 31, 2017

http://dx.doi.org/10.18006/2017.5(5).662.672

\section{KEYWORDS \\ Apple \\ Agrobacterium tumefaciens \\ Chitinase}

Genetic Transformation

Rootstock M7

\begin{abstract}
In most of the fruit crops, the low frequency of Agrobacterium mediated genetic transformation hampers the respective transgenics production. Hence, it is pre-requisite to understand and optimize the different parameters involved directly or indirectly in Agrobacterium mediated transformation. A. tumefaciens strain LBA4404 harboring the transforming vector pCAMBARchil1 containing the rice chitinase gene (chill) and hygromycin phosphotransferase (hpt) and phosphinothricin acetyl transferase (bar) genes was used for carrying out genetic transformation of apple (Malus x domestica Borkh.) rootstock M7. Two explants viz. leaf and internodal segments were involved in regeneration and resulted $24.37 \%$ and $60.58 \%$ shoot regeneration, respectively. The obtained putative transformants were selected on full strength MS medium containing $5 \mathrm{mg} \mathrm{l}^{-1}$ hygromycin and $500 \mathrm{mg}^{-1}$ cefotaxime. Two days pre-culturing and 96 hours co-cultivation was found effective for procuring maximum number of hygromycin resistant shoots. Putative transgenic shoots were multiplied separately and rooted on root induction medium containing $5 \mathrm{mg} \mathrm{l}^{-1}$ hygromycin. Further, PCR analysis was done using chitinase gene specific primers and two apple transgenic lines confirmed the integration of chill gene by yielding $237 \mathrm{bp}$ and 584 bp amplified products, respectively.
\end{abstract}

* Corresponding author

E-mail: tulip.parul@yahoo.co.in (Sharma Parul)

Peer review under responsibility of Journal of Experimental Biology and Agricultural Sciences.

Production and Hosting by Horizon Publisher India [HPI] (http://www.horizonpublisherindia.in/).

All rights reserved.
All the article published by Journal of Experimental Biology and Agricultural Sciences is licensed under a Creative Commons Attribution-NonCommercial 4.0 International License Based on a work at www.jebas.org.

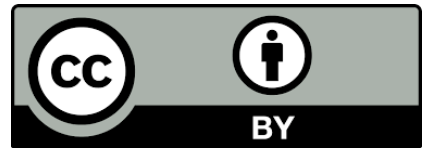




\section{Introduction}

The domesticated apple is one of the most important fruit crops of the colder and temperate parts of the world. It belongs to the family Rosaceae, subfamily Maloideae, and the farmed apple tree with a pomaceous fruit is known as Malus $x$ domestica Borkhausen (Harris et al., 2002). The long juvenile period, high levels of heterozygosity, long hybrid evaluation time and the process of releasing new cultivars are the critical factors which slow down the pace of various conventional apple breeding programmes. So there is an urgent need to adopt modern biotechnological tools which could help to accelerate this process. Plant genetic transformation using desirable genes has geared up and facilitated various apple crop improvement activities by targeting resistance to fungal or bacterial diseases, improved fruit quality, or root stocks with better rooting or dwarfing ability (Igarashi et al., 2016). Among fruit crops, domesticated apple attains the distinctiveness because of the availability of a wide range of clonal rootstocks, thereby permitting the development of a 'designer tree size' appropriate for high density plantations. The inherent characteristics of these rootstocks especially disease resistance, growth and flowering habits etc. has remarkable impression on scion varieties. In Indian conditions, rootstock like Malling 7 (M7) is recommended as it is virus-free, and has proven itself to be one of the most popular rootstocks in the commercial industry, mostly due to its capability of producing a semi-dwarf tree i.e. approximately $50-60 \%$ of standard size. It is tolerant to collar rot, a major soil-borne disease of apple. While, it shows susceptibility to a serious soil borne disease 'white root rot' caused by the fungus Dematophora necatrix Hartig.

There are number of limiting factors which restricts various plant disease management practices to some extent. Plant genetic transformation has emerged as a powerful and attractive strategy for the genetic improvement of fruit trees constrained by their reproductive biology and high levels of heterozygosity. This strategy has emerged as a promising tool and addressed various problems while opening new avenues for crop modification (Rao et al., 2009). Agrobacterium- mediated transformation is widely used gene transfer method for introducing foreign genes into dicotyledonous plants. In this process, type of Agrobacterium strain, disarmed binary vector and explant (leaf, hypocotyl or callus cultures) are the limiting factors for an efficient transformation. Reliable and highly efficient regeneration system is pre-requisite base for the development of successful transformation protocol in any crop. Hence, these biotechnological based strategies can be considered as an important supplement along with existing technologies to speed up various fruit crop improvement programmes.

Innate defense mechanisms assist plants to respond towards various biotic stresses. Several researchers have demonstrated that many defense-related (DR) proteins, such as pathogenesis-related proteins (PR) and anti-microbial peptides (AMP) have been identified in different plants during biotic stress. Chitinases are the enzymes that rupture chitin i.e. the primary component of cell walls of several types of fungi and exoskeletons of invertebrates by hydrolyzing the $\beta$-1,4-linkage among $\mathrm{N}$-acetylglucosamine units (Datta et al., 1999).

For enhancing disease resistance in apple, a chitinase gene from different sources was introduced for the first time against apple scab causal organism (Wong et al., 1999; Bolar et al., 2000). An efficient plant regeneration system along with gene transfer and selection system guarantees the genetic advancement of apple through transgenic production. However, low regeneration frequency as compared to those of herbaceous species keeps genetic transformation studies in apple lacked behind. Therefore, considering such kind of key limiting factors, we aimed at developing a simple and reliable genetic transformation protocol using antifungal chitinase gene in commercially important apple rootstock $\mathrm{M} 7$ rootstock.

\section{Materials and Methods}

\subsection{Explants used}

4-5 weeks old in vitro proliferating cultures (raised from axillary buds) of apple rootstock M7 were used for procuring two explants i.e. leaves and internodal segments.

\subsection{Shoot regeneration experiments}

The selected explants i.e. leaves and internodal segments were excised, wounded and then inoculated on solid shoot regeneration medium (RM) containing MS salts and vitamins (Murashige \& Skoog, 1962) fortified with varying concentrations $\left(\mathrm{mg} \mathrm{l}^{-1}\right)$ of cytokinins as mentioned in Tables 1 and 2. Further, regenerated shoots were multiplied on shoot multiplication medium (MM) i.e. MS salts and vitamins supplemented with benzyl adenine (BA) $0.5 \mathrm{mg} \mathrm{l}^{-1}$, gibberellic acid $\left(\mathrm{GA}_{3}\right) 0.5 \mathrm{mg} \mathrm{l}^{-1}$, indole-3-butyric acid (IBA) $0.1 \mathrm{mg} \mathrm{l}^{-1}$ for multiplication. $2.0-3.0 \mathrm{~cm}$ long regenerants were cut and induced to root by dipping in half strength MS liquid medium containing $0.5 \mathrm{mg} \mathrm{l}^{-1}$ thiamine, $20 \mathrm{~g} \mathrm{l}^{-1}$ sucrose and 0.3 $\mathrm{mg} \mathrm{l}^{-1}$ IBA. These were incubated in dark for initial first week and then transferred to basal solidified medium and then kept in light. For hardening, rooted shoots were washed gently. After four weeks, well established plantlets were transferred to earthen pots containing sand, soil and FYM (1:1:1 w/w). The plants were acclimatized by gradually exposing to natural conditions. 
Table 1 Effect of growth regulators on leaf explants for callus induction and adventitious shoot regeneration

\begin{tabular}{|c|c|c|c|c|c|c|c|}
\hline \multirow[t]{2}{*}{ S. No. } & \multirow{2}{*}{$\begin{array}{l}\text { Medium } \\
\text { code }\end{array}$} & \multicolumn{4}{|c|}{ Plant growth regulators $\left(\mathrm{mg} \mathrm{l}^{-1}\right)$} & \multirow{2}{*}{$\begin{array}{l}\text { Frequency of callus } \\
\text { induction }(\%)\end{array}$} & \multirow{2}{*}{$\begin{array}{c}\text { Frequency of shoot } \\
\text { regeneration }(\%)\end{array}$} \\
\hline & & BA & $\mathrm{TDZ}$ & NAA & IAA & & \\
\hline 1 & RM1 & 2.0 & - & 0.5 & - & $64.72(53.56)^{*}$ & $0.00(1.00)^{* *}$ \\
\hline 2 & $\mathrm{RM} 2$ & 3.0 & - & 0.5 & - & $62.85(52.44)^{*}$ & $0.00(1.00) * *$ \\
\hline 3 & RM3 & 4.0 & - & 0.5 & - & $60.7(51.22) *$ & $0.00(1.00) * *$ \\
\hline 4 & RM4 & 5.0 & - & 0.5 & - & $60.58(51.11)^{*}$ & $0.00(1.00) * *$ \\
\hline 5 & RM5 & 2.0 & - & 1.0 & - & $70.19(56.91)^{*}$ & $0.00(1.00) * *$ \\
\hline 6 & RM6 & 3.0 & - & 1.0 & - & $72.46(58.35)^{*}$ & $0.00(1.00) * *$ \\
\hline 7 & RM7 & 4.0 & - & 1.0 & - & $74.71(59.81)^{*}$ & $4.16(2.27) * *$ \\
\hline 8 & RM8 & 5.0 & - & 1.0 & - & $73.53(59.04)^{*}$ & $0.00(1.00) * *$ \\
\hline 9 & RM9 & 2.0 & - & - & 0.5 & $0.00(0.00) *$ & $0.00(1.00) * *$ \\
\hline 10 & RM10 & 3.0 & - & - & 0.5 & $0.00(0.00) *$ & $0.00(1.00) * *$ \\
\hline 11 & RM11 & 4.0 & - & - & 0.5 & $0.00(0.00) *$ & $0.00(1.00) * *$ \\
\hline 12 & RM12 & 5.0 & - & - & 0.5 & $0.00(0.00) *$ & $0.00(1.00) * *$ \\
\hline 13 & RM13 & 2.0 & - & - & 1.0 & $0.00(0.00) *$ & $0.00(1.00) * *$ \\
\hline 14 & RM14 & 3.0 & - & - & 1.0 & $0.00(0.00) *$ & $0.00(1.00) * *$ \\
\hline 15 & RM15 & 4.0 & - & - & 1.0 & $0.00(0.00) *$ & $0.00(1.00) * *$ \\
\hline 16 & RM16 & 5.0 & - & - & 1.0 & $0.00(0.00) *$ & $1.38(1.54) * *$ \\
\hline 17 & RM17 & - & 0.2 & 0.5 & - & $82.00(64.90)^{*}$ & $0.00(1.00) * *$ \\
\hline 18 & RM18 & - & 0.4 & 0.5 & - & $82.27(65.10)^{*}$ & $0.00(1.00) * *$ \\
\hline 19 & RM19 & - & 0.6 & 0.5 & - & $83.63(66.14)^{*}$ & $9.71(3.27) * *$ \\
\hline 20 & RM20 & - & 0.8 & 0.5 & - & $85.41(67.54)^{*}$ & $18.05(4.35) * *$ \\
\hline 21 & RM21 & - & 1.0 & 0.5 & - & $84.81(67.06)^{*}$ & $0.00(1.00) * *$ \\
\hline 22 & RM22 & - & 0.2 & 1.0 & - & $88.05(69.78)^{*}$ & $0.00(1.00) * *$ \\
\hline 23 & RM23 & - & 0.4 & 1.0 & - & $88.09(69.81)^{*}$ & $0.00(1.00) * *$ \\
\hline 24 & RM24 & - & 0.6 & 1.0 & - & $88.51(70.19)^{*}$ & $0.00(1.00) * *$ \\
\hline 25 & RM25 & - & 0.8 & 1.0 & - & $89.50(71.09)^{*}$ & $24.37(5.03) * *$ \\
\hline 26 & RM26 & - & 1.0 & 1.0 & - & $87.85(69.60)^{*}$ & $0.00(1.00) * *$ \\
\hline 27 & RM27 & - & 0.2 & - & 0.5 & $37.17(37.56)^{*}$ & $0.00(1.00) * *$ \\
\hline 28 & RM28 & - & 0.4 & - & 0.5 & $37.20(37.58)^{*}$ & $0.00(1.00) * *$ \\
\hline 29 & RM29 & - & 0.6 & - & 0.5 & $37.58(37.81)^{*}$ & $0.00(1.00) * *$ \\
\hline 30 & RM30 & - & 0.8 & - & 0.5 & $37.59(38.02)^{*}$ & $0.00(1.00) * *$ \\
\hline 31 & RM31 & - & 1.0 & - & 0.5 & $36.61(37.23)^{*}$ & $0.00(1.00) * *$ \\
\hline 32 & RM32 & - & 0.2 & - & 1.0 & $41.00(39.81)^{*}$ & $0.00(1.00) * *$ \\
\hline 33 & RM33 & - & 0.4 & - & 1.0 & $42.03(40.41)^{*}$ & $0.00(1.00) * *$ \\
\hline 34 & RM34 & - & 0.6 & - & 1.0 & $41.63(40.18)^{*}$ & $0.00(1.00) * *$ \\
\hline 35 & RM35 & - & 0.8 & - & 1.0 & $41.66(40.20)^{*}$ & $0.00(1.00) * *$ \\
\hline 36 & RM36 & - & 1.0 & - & 1.0 & $40.86(39.73)^{*}$ & $0.00(1.00) * *$ \\
\hline \multicolumn{6}{|c|}{$\mathrm{CD}_{0.05}$} & $3.36(2.34) *$ & $8.40(0.65) * *$ \\
\hline \multicolumn{6}{|c|}{$\mathrm{SE}(\mathrm{m})$} & $1.18(0.83)^{*}$ & $2.97(0.23)^{* *}$ \\
\hline
\end{tabular}

(Values in parentheses are - *angular and **square root transformed values) 
Table 2 Effect of growth regulators on internodal explants for callus induction and adventitious shoot regeneration

\begin{tabular}{|cccccc|} 
Sr. No. & Medium code & \multicolumn{2}{c}{$\begin{array}{c}\text { Plant growth regulators } \\
\left(\mathrm{mg} \mathrm{l}^{-1}\right)\end{array}$} & Frequency of callus induction & $\begin{array}{c}\text { Frequency of shoot regeneration } \\
(\%)\end{array}$ \\
\hline 1 & & TDZ & NAA & $24.33(29.52)$ & $12.75(20.89)$ \\
\hline 2 & RM1 & 0.2 & 0.5 & $20.50(26.90)$ & $28.17(32.04)$ \\
\hline 3 & RM2 & 0.4 & 0.5 & $17.83(24.96)$ & $39.67(39.02)$ \\
\hline $\mathbf{4}$ & RM3 & 0.6 & 0.5 & $\mathbf{1 5 . 3 3 ( 2 3 . 0 4 )}$ & $\mathbf{6 0 . 5 8 ( 5 1 . 0 9 )}$ \\
\hline 5 & RM4 & $\mathbf{0 . 8}$ & $\mathbf{0 . 5}$ & $12.50(20.68)$ & $41.83(40.27)$ \\
\hline 6 & RM5 & 1.0 & 0.5 & $40.50(39.50)$ & $8.33(16.75)$ \\
\hline 7 & RM6 & 0.2 & 1.0 & $37.75(37.89)$ & $19.75(26.37)$ \\
\hline 8 & RM7 & 0.4 & 1.0 & $31.50(34.12)$ & $27.67(31.72)$ \\
\hline 9 & RM8 & 0.6 & 1.0 & $29.00(32.56)$ & $29.42(32.83)$ \\
\hline 10 & RM9 & 0.8 & 1.0 & $21.33(27.47)$ & $15.17(22.90)$ \\
\hline & RM10 & 1.0 & 1.0 & $2.67(1.80)^{*}$ & $2.33(1.52)^{*}$ \\
\hline
\end{tabular}

(Values in parentheses are angular transformed values)

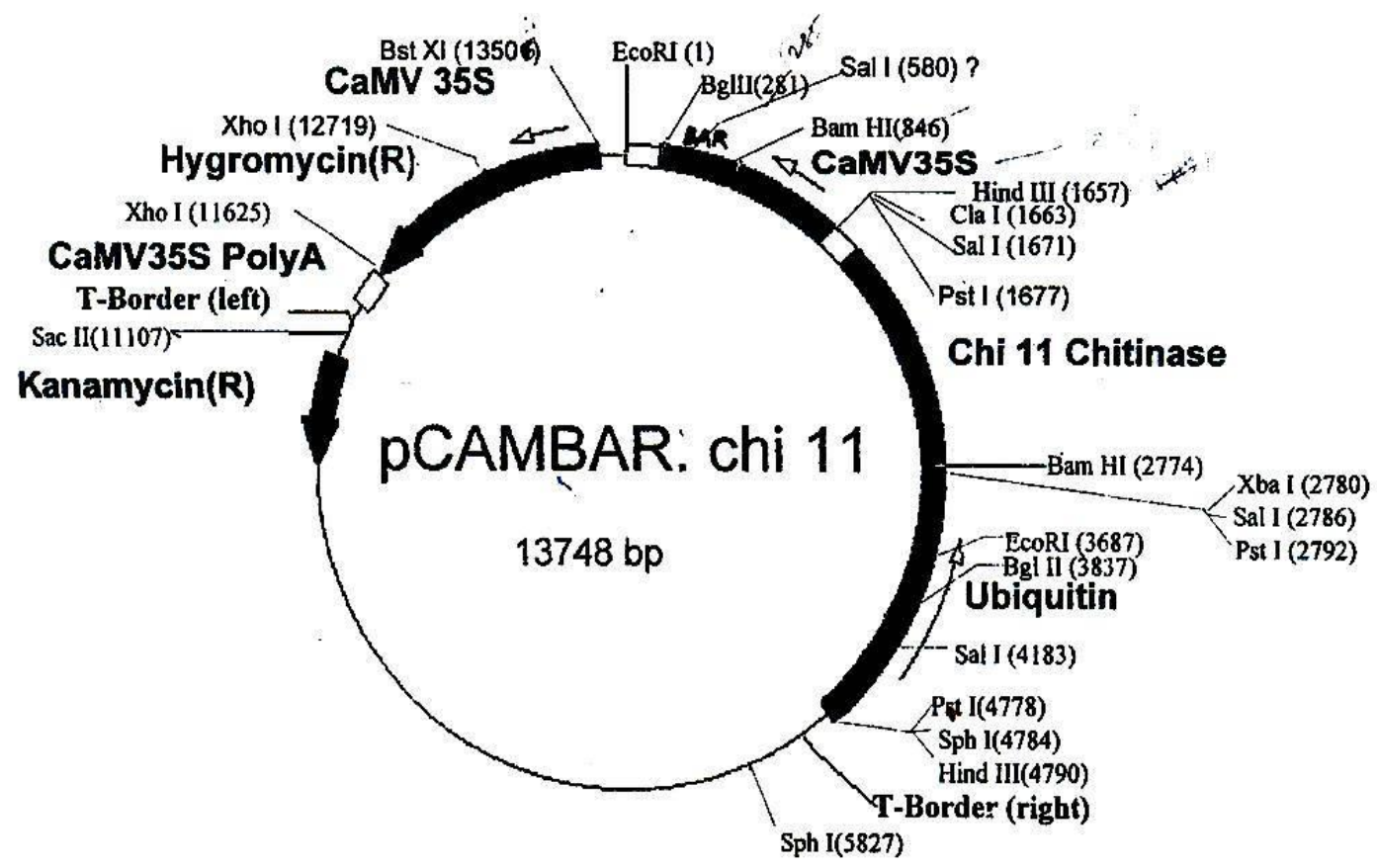

Figure 1 Map of pCAMBIA bar-ubi-chill transforming vector

\subsection{Genetic transformation experiments}

The chitinase gene construct harboring plasmid pCAMBIA barubi-chi II (13.8 kb, Figure 1) with chitinase (chi-II, $1.1 \mathrm{~kb}$ ) gene driven by ubiquitin-I (Ubi-I) promoter and two selectable marker genes i.e., hygromycin phosphotransferase (hpt) \& phosphinothricin acetyltransferase (bar) under the control of CaMV35S was obtained from Dr S. Muthukrishnan, KSU, USA. Further, plasmid DNA was transferred into A. tumefaciens strain LBA4404 via triparental mating by Sharma et al. (2012) for carrying out co-cultivation experiments. 


\subsection{Strain maintenance}

The A. tumefaciens strain LBA4404 was regularly maintained on YMB (Yeast extract $1.0 \mathrm{~g} \mathrm{l}^{-1}$, Mannitol $10.0 \mathrm{~g} \mathrm{l}^{-1}$, Dipotassium phosphate $0.5 \mathrm{~g} \mathrm{l}^{-1}$, Magnesium sulphate $0.2 \mathrm{~g} \mathrm{l}^{-1}$, Sodium chloride $0.1 \mathrm{~g} \mathrm{l}^{-1}$, Calcium carbonate $1.0 \mathrm{~g} \mathrm{l}^{-1}$, Final $\mathrm{pH}$ 7.0) medium containing filter sterilized streptomycin $\left(25 \mathrm{mg} \mathrm{l}^{-1}\right)$ and kanamycin $\left(50 \mathrm{mg} \mathrm{l}^{-1}\right.$ ) (Hi-Media) respectively. To achieve proper growth, incubation at $28^{\circ} \mathrm{C}$ under dark conditions for 3-4 days and further storage at low temperature $\left(4 \pm 2{ }^{0} \mathrm{C}\right)$ was followed.

\subsection{Bacterial suspension preparation}

For co-cultivation, fresh cultures of Agrobacterium strain LBA4404 were prepared in $25 \mathrm{ml}$ liquid YMB medium containing $50 \mathrm{mg} \mathrm{l}^{-1}$ kanamycin (filter sterilized) and incubated overnight at $28{ }^{\circ} \mathrm{C}$ in an orbital shaker at $200 \mathrm{rpm}$. Bacterial suspension was centrifuged at 6,000 rpm for 5 minutes and the pellet was resuspended in MS basal liquid medium to a O.D. $=0.520$ at 540 $\mathrm{nm}$ pertaining to $5 \times 10^{8}$ cells per $\mathrm{ml}$.

\subsection{Antibiotics used}

Two antibiotics i.e. hygromycin for transformants selection and cefotaxime for controlling A. tumefaciens growth were used. $5 \mathrm{mg}$ $\mathrm{l}^{-1}$ Hygromycin and $500 \mathrm{mg} \mathrm{l}^{-1}$ cefotaxime were added to presterilized molten MS regeneration medium (RM) fortified with $0.8 \mathrm{mg}^{-1} \mathrm{TDZ}$ and $1.0 \mathrm{mg}^{-1} \mathrm{NAA}$ by filter sterilization through $0.22 \mu \mathrm{m}$ pore size membrane filter to carry out the respective transformation experiments.

\subsection{Pre-culturing and co-cultivation experiments}

Both types of explants were pre-cultured for 2 days in light prior to infection on RM and then further, co-cultivated on selective RM supplemented with $5 \mathrm{mg} \mathrm{l}^{-1}$ Hygromycin and $500 \mathrm{mg}^{-1}$ cefotaxime. The pre-cultured explants were immersed in bacterial suspension for 15 minutes with gentle pricking and stirring for infection with Agrobacterium. Explants were further blotted on sterilized filter paper to remove the excess of bacteria and placed on basal MS medium after Agrobacterium infection. The cultures were co-cultivated/incubated for 96 hours in dark and observations were recorded on the basis of morphological evidences i.e. Agrobacterium growth and the average number of calli or shoots formed from survived explants after four weeks, respectively. Both types of explants were transferred to selective RM medium containing $500 \mathrm{mg} \mathrm{l}^{-1}$ cefotaxime to eliminate the bacteria and $5 \mathrm{mg} \mathrm{l}^{-1}$ hygromycin to select the putative transformed shoots following 96 hours (dark) of co-cultivation. Explants were washed with sterile distilled water containing 250 mg $\mathrm{l}^{-1}$ cefotaxime, blotted on sterilized filter paper and then transferred on fresh selective RM to check the excessive bacterial growth. The performance of putative transformed cells or shoots was compared with control on selective medium as well as on non-selective medium. Depending upon the growth of Agrobacterium, the concentration of cefotaxime was decreased gradually from 500 to $250 \mathrm{mg} \mathrm{l}^{-1}$. 26 putative regenerants of length $(\geq 0.5 \mathrm{~cm})$ were separated off from the explant and multiplied on selective MM supplemented with $5 \mathrm{mg} \mathrm{l}^{-1}$ hygromycin and $250 \mathrm{mg}^{-1}$ cefotaxime. Of these, only 18 selected putative shoots (about $0.5-1.0 \mathrm{~cm}$ ) were rooted and hardened.

\subsection{Molecular level confirmation}

Genomic DNA from leaves of 2 untransformed control shoots and 18 hygromycin resistant shoots were isolated following CTAB method and further quantitative and qualitative analysis was done using UV spectrophotometer (Bio-Rad). Two sets of specific primers for the amplification of rice endochitinase class I (chilI) gene were designed with their product size 237 bp (forward primer- GGACGCAGTCTCCTTCAAGA, reverse primerATGTCGCAGTAGCGCTTGTA) and 584 bp (forward primerGCTTCTACACCTACGACGCCTT, reverse primerGTAGCGCTTGTAGAACCCGATC), respectively to check the integration of T-DNA in the genome of putative transformants. PCR conditions were standardized for these primers by using isolated DNA along with two PCR controls i.e, positive control (plasmid DNA) and negative control (reaction mix with water except template DNA) in a thermal cycler (Eppendorf). $25 \mu \mathrm{lPCR}$ cocktail consisted of 3U/reaction Taq DNA polymerase, 10x Taq DNA polymerase buffer, $1.5 \mathrm{mM} \mathrm{MgCl}, 10 \mathrm{pmol} / \mathrm{reaction}$ each specific chitinase primers (forward and reverse), $2.5 \mathrm{mM}$ each dNTPs (deoxynucleotide triphosphate) and $50 \mathrm{ng} /$ reaction template DNA respectively. Amplified PCR products were visualized and photographed under UV light using alpha imager ${ }^{\circledR}$ EC gel documentation system (Biovis) after electrophoresis on a $1.2 \%$ (w/v) agarose gel containing $0.5 \mu \mathrm{g} \mathrm{ml}^{-1}$ ethidium bromide.

\subsection{Data analysis}

The statistical analysis based on mean values per treatment was made using ANOVA technique for completely randomized design (CRD).

\section{Results}

\subsection{Adventitious shoot regeneration studies}

Instead of various other auxin and cytokinin combinations, adventitious shoots emerged only in TDZ and NAA combinations in case of both the explants (leaf and internodal segments). In case of leaf explants, from 16 different combinations of BA and NAA/IAA used, only RM7 and RM16 combinations produced adventitious shoots with a frequency of $4.16 \%$ and $1.38 \%$ respectively (Table 1). Likewise, out of 20 different combinations of TDZ and NAA/IAA, an average frequency of adventitious 
shoot regeneration of $24.37 \%, 18.05 \%$ and $9.71 \%$ was achieved in RM25 (0.8 $\mathrm{mg} \mathrm{l}^{-1} \mathrm{TDZ}$ and $\left.1.0 \mathrm{mg} \mathrm{l}^{-1} \mathrm{NAA}\right)$, RM20 (0.8 $\mathrm{mg} \mathrm{l}^{-1}$ TDZ and $\left.0.5 \mathrm{mg} \mathrm{l}^{-1} \mathrm{NAA}\right)$ and RM19 (0.6 $\mathrm{mg}^{-1} \mathrm{TDZ}$ and $0.5 \mathrm{mg}$ $\mathrm{I}^{-1}$ NAA) respectively (Table 1 ). On the other hand, TDZ and IAA combinations failed to produce adventitious shoots. Only RM25 $\left(0.8 \mathrm{mg} \mathrm{l}^{-1} \mathrm{TDZ}\right.$ and $\left.1.0 \mathrm{mg} \mathrm{l}^{-1} \mathrm{NAA}\right)$ showed both direct and indirect organogenesis (Figure 2). While assessing the frequency of adventitious shoot regeneration, internodal segments were found better than the leaf explants. The most significant treatment was $0.8 \mathrm{mg} \mathrm{l}^{-1} \mathrm{TDZ}$ and $0.5 \mathrm{mg} \mathrm{l}^{-1} \mathrm{NAA}$ with a maximum of $60.58 \%$ regeneration in case of internodal segments (Table 2, Figure 3). Although both leaf and internodal explants showed good regeneration rates with TDZ and NAA combinations but later showed relatively higher regeneration rate. Regenerated shoots were propagated on shoot multiplication medium (MM). About $70-75 \%$ rooting was noted in the regenerants with $50-60 \%$ hardening rate.

\subsection{Effect of antibiotics}

Optimization of antibiotics dosage is compulsory as it determines the basic pre-requisites like normal regeneration of putative transgenic shoots and controlled Agrobacterium growth.
Cefotaxime @ $500 \mathrm{mg} \mathrm{l}^{-1}$ controlled the excessive Agrobacterium growth effectively after co-cultivation along with less regeneration frequency. While lower concentrations of cefotaxime i.e. $200-300 \mathrm{mg} \mathrm{l}^{-1}$ triggered the regeneration. On the other hand, 5 $\mathrm{mg} \mathrm{l}^{-1}$ hygromycin proved effective for the selection of putative transformants after co-cultivation. In this study, data with respect to antibiotics standardization have not shown.

\subsection{Genetic transformation experiments}

Following 15 minutes infection of explants with Agrobacterium cell suspension $\left(5 \times 10^{8}\right.$ cells $\left./ \mathrm{ml}\right)$ with gentle stirring, co-cultivation for 96 hours in all the precultured leaf and internodal explants (Tables $3 \& 4$ ) had a strong impact on the regeneration frequency i.e. $1.75 \& 7.66$ as well as the number of putative transformed shoots i.e. $1.33 \& 3.33$, respectively. A total of 26 putative transgenic shoots from both the explants i.e. leaves and internodes (Figure 4) were obtained and maintained separately on selective (5 $\mathrm{mg} \mathrm{l}^{-1}$ hygromycin and $250 \mathrm{mg} \mathrm{l}^{-1}$ cefotaxime) MM. Upon subculturing, the non-transformed tissues or the escapes shoots, which became necrotic or white, were removed. The putative transformed shoots revealed a steady growth pattern as compared to control. In present study, leaf explants predominantly generated

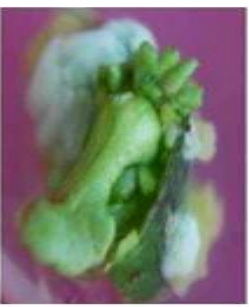

(a)

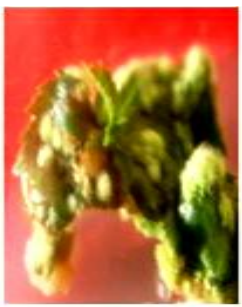

(b)

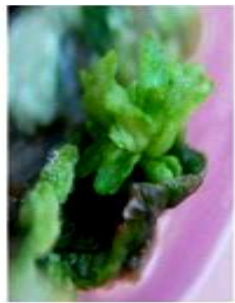

(c)

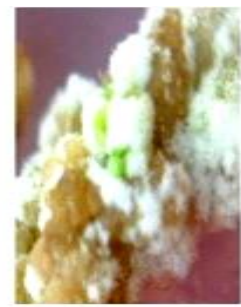

(d)

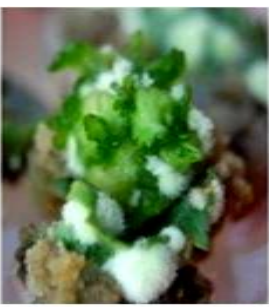

(e)

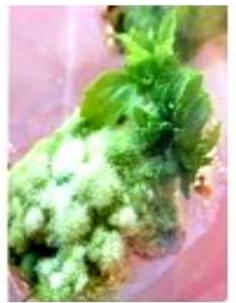

(f)

Figure 2 Shoot regeneration in leaf explants; (a-c) Direct \& (d-f) Indirect regeneration on MS salts \& vitamins +0.8 $\mathrm{mg} / \mathrm{l} \mathrm{TDZ}+1.0 \mathrm{mg} / \mathrm{l} \mathrm{NAA}(\mathrm{RM} 25)$.

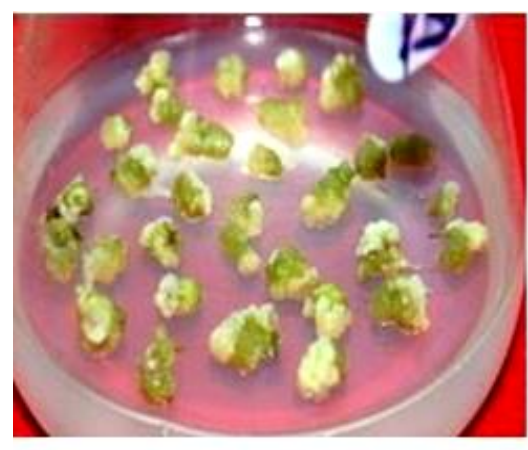

(a)

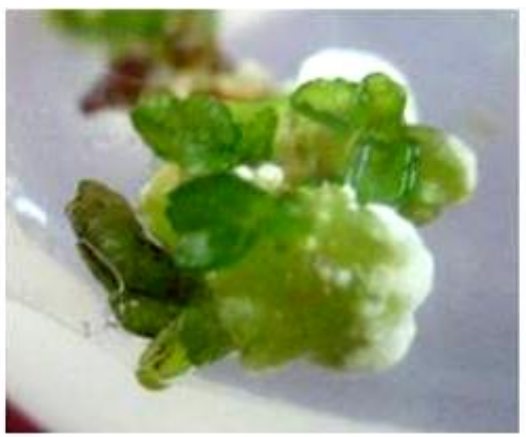

(b)

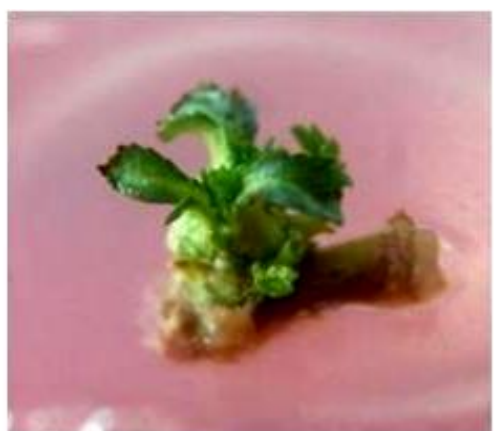

(c)

Figure 3 Shoot regeneration in internodes (a-c) on MS salts \& vitamins $+0.8 \mathrm{mg} / \mathrm{l}$ TDZ+0.5 mg/l NAA (RM 4). 
Table 3 Effect of pre-culturing and co-cultivation durations on regeneration of leaf explants

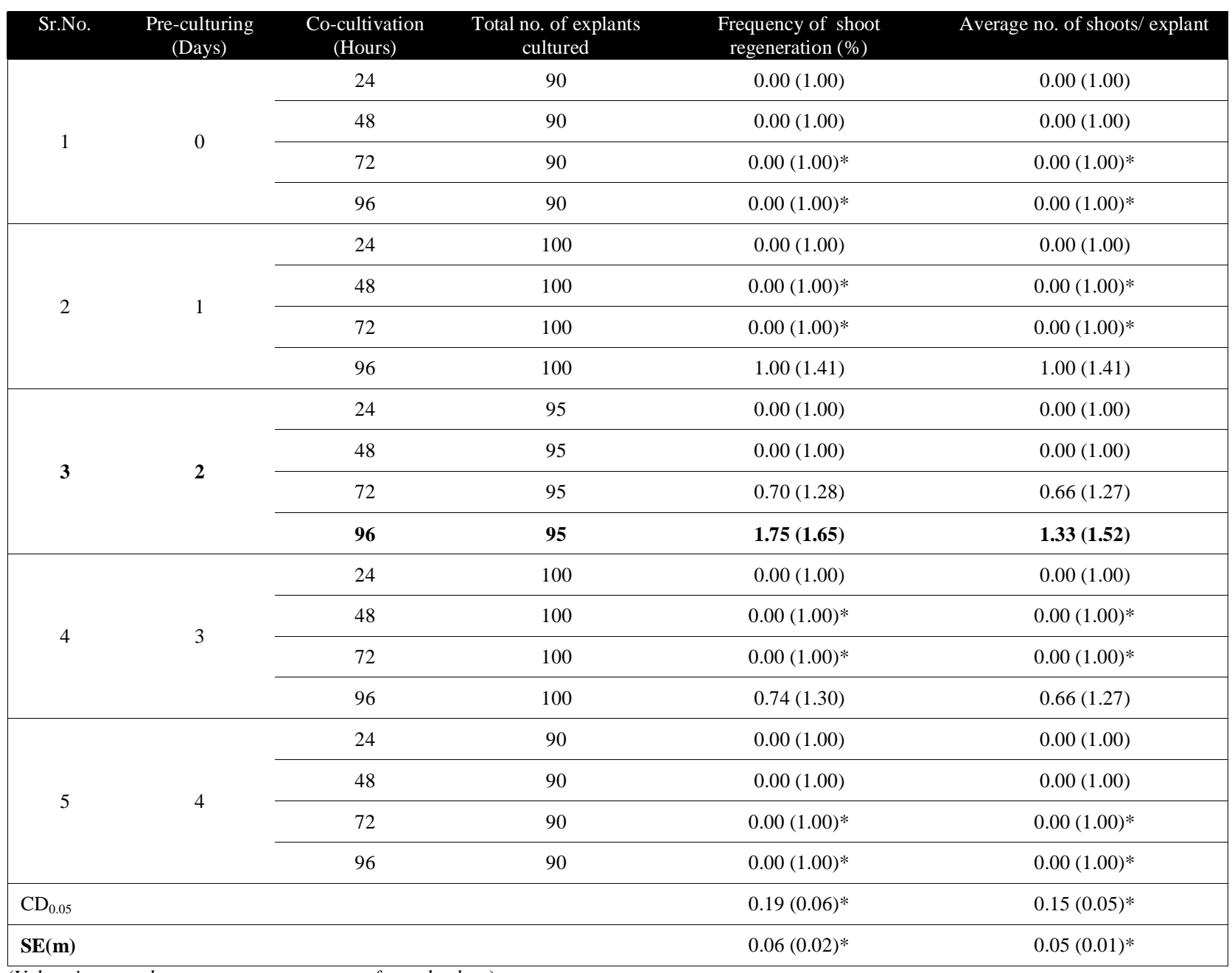

(Values in parentheses are square root transformed values)

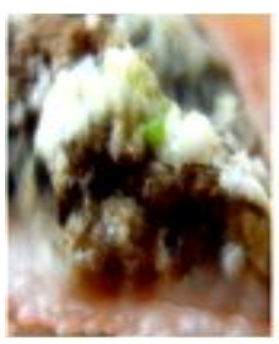

(a)

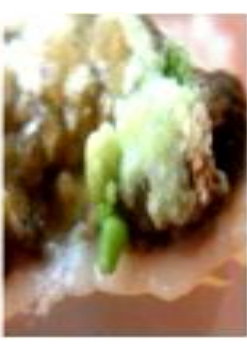

(b)

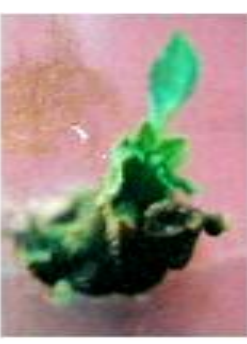

(c)

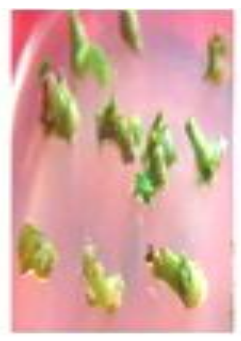

(d)

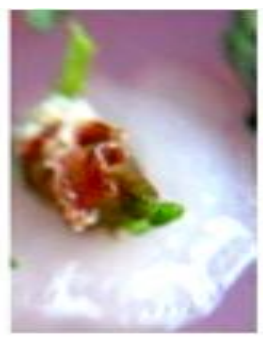

(e)

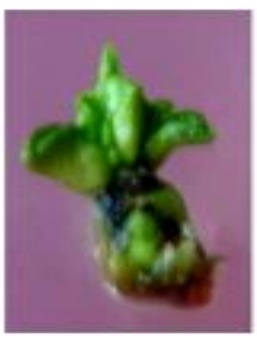

(f)

Figure 4 Putative transformed shoot regeneration on selective medium (a-c) through leaf explants (d-f) through internodes 
Table 4 Effect of pre-culturing and co-cultivation durations on regeneration of internodal segments

\begin{tabular}{|c|c|c|c|c|c|}
\hline Sr.No. & $\begin{array}{l}\text { Pre-culturing } \\
\text { (Days) }\end{array}$ & Co-cultivation (Hours) & $\begin{array}{c}\text { Total no. of explants } \\
\text { cultured }\end{array}$ & $\begin{array}{c}\text { Frequency of shoot } \\
\text { regeneration }(\%)\end{array}$ & $\begin{array}{l}\text { Average no. of shoots/ } \\
\text { explant }\end{array}$ \\
\hline \multirow{4}{*}{1} & \multirow{4}{*}{0} & 24 & 70 & $0.00(1.00)$ & $0.00(1.00)$ \\
\hline & & 48 & 70 & $0.00(1.00)$ & $0.00(1.00)$ \\
\hline & & 72 & 70 & $1.17(1.43)$ & $1.00(1.38)$ \\
\hline & & 96 & 70 & $1.95(1.65)$ & $1.33(1.48)$ \\
\hline \multirow{4}{*}{2} & \multirow{4}{*}{1} & 24 & 55 & $0.00(1.00)$ & $0.00(1.00)$ \\
\hline & & 48 & 55 & $0.00(1.00)$ & $0.00(1.00)$ \\
\hline & & 72 & 55 & $2.33(1.82)$ & $1.66(1.62)$ \\
\hline & & 96 & 55 & $4.33(2.30)$ & $1.66(1.62)$ \\
\hline \multirow{4}{*}{3} & \multirow{4}{*}{2} & 24 & 60 & $0.00(1.00)$ & $0.00(1.00)$ \\
\hline & & 48 & 60 & $0.00(1.00)$ & $0.00(1.00)$ \\
\hline & & 72 & 60 & $4.00(2.22)$ & $2.33(1.82)$ \\
\hline & & 96 & 60 & $7.66(2.92)$ & $3.33(2.07)$ \\
\hline \multirow{4}{*}{4} & \multirow{4}{*}{3} & 24 & 50 & $0.00(1.00)$ & $0.00(1.00)$ \\
\hline & & 48 & 50 & $0.00(1.00)$ & $0.00(1.00)$ \\
\hline & & 72 & 50 & $2.35(1.81)$ & $1.66(1.62)$ \\
\hline & & 96 & 50 & $5.87(2.61)$ & $2.00(1.71)$ \\
\hline \multirow{4}{*}{5} & \multirow{4}{*}{4} & 24 & 55 & $0.00(1.00)$ & $0.00(1.00)$ \\
\hline & & 48 & 55 & $0.00(1.00)$ & $0.00(1.00)$ \\
\hline & & 72 & 55 & $1.11(1.45)$ & $1.00(1.41)$ \\
\hline & & 96 & 55 & $0.74(1.30)$ & $0.66(1.27)$ \\
\hline \multicolumn{4}{|c|}{$\mathrm{CD}_{0.05}$} & $0.93(0.26)^{*}$ & $0.46(0.13)^{*}$ \\
\hline \multicolumn{4}{|c|}{ SE (m) } & $0.32(0.09)^{*}$ & $0.16(0.04)^{*}$ \\
\hline
\end{tabular}

(Values in parentheses are square root transformed values)

the putative shoots directly i.e. without callus phase. On the other hand, internodal segments generated the putative shoots indirectly i.e. through callus phase.

\subsection{Molecular level confirmation}

Integration of the chitinase gene in 18 putative transgenic shoots was checked by PCR analysis. Only two lines (T3 and T9) out of 18 were proved PCR positive by amplifiying $237 \mathrm{bp}$ and $584 \mathrm{bp}$ fragments (Figure 5a \& 5b) respectively. Consequently, the presence and integration of chitinase gene in the genome of apple rootstock M7 was demonstrated by PCR analysis. Hardening was attempted in case of rooted transgenic lines (Figure 6).

\subsection{Transformation efficiency}

In the present studies, the observed transformation efficiency with respect to the type of explants viz. leaf and internode was $0.32 \%$ and $1.70 \%$. Out of two transgenic lines, one arose from leaf explants and another from internodes. Correspondingly, the actual transformation frequency was $0.05 \%$ and $0.08 \%$ in leaf and internodal explants.

\section{Discussion}

With the emergence of genetic transformation method the chances for the development of resistant cultivars have been increased in 


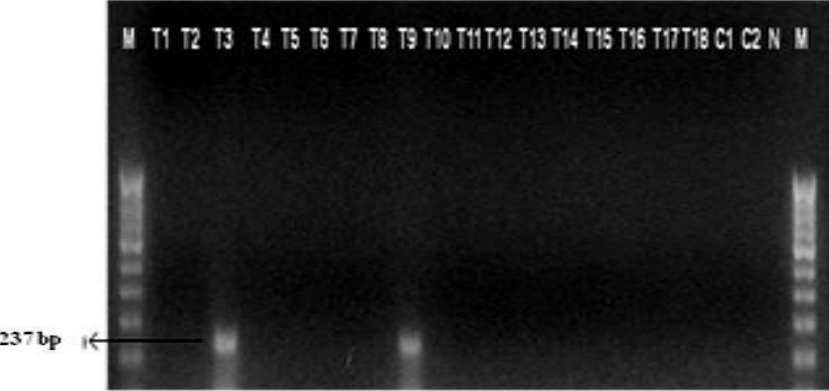

(a)

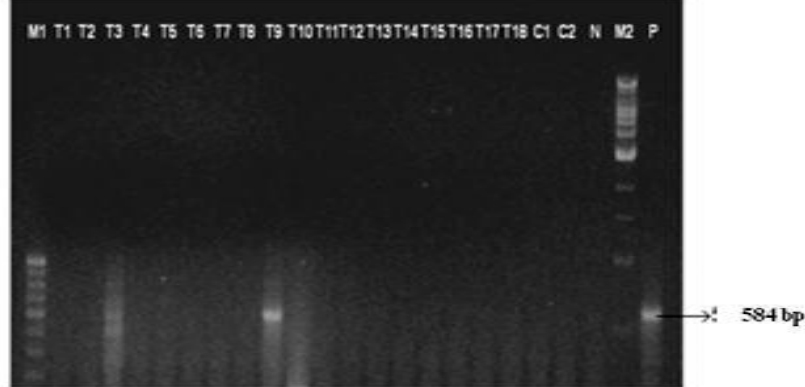

(b)

Figure 5 (a) 237 bp \& (b) 584 bp amplification in T3 and T9 transgenic lines.

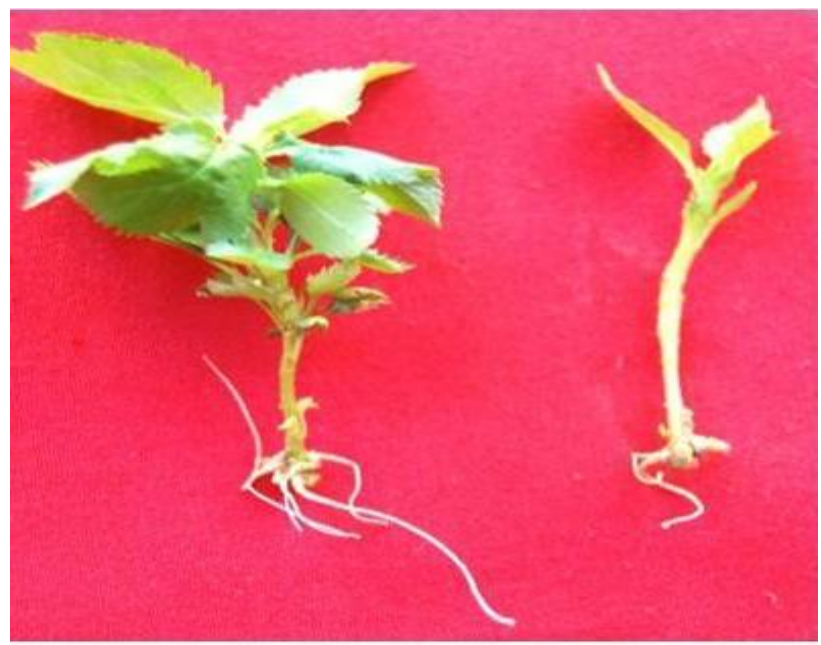

(a)

(b)

Figure 6 Rooting in (a) control (b) transgenic line.

case of important commercial apple cultivars and rootstocks vulnerable to various fungal diseases. Genetic engineering widens the swiftness of genes by transferring them to plants from any other source like plants, animals or microorganisms which is usually limited in conventional breeding programs (Polanco et al., 2010). Many of the species and cultivars of apple perform poorly towards the development of transgenic tissues because of inefficacious regeneration system (Akdemir et al., 2012. Increased leaf regeneration efficiency remains to be the most imperative factor for development of a transformation system in apple while using A. tumefaciens vectors. Axenically raised shoot tissue cultures serves as a perfect source for explants like expanded leaves or stems. For adventitious shoot bud/shoots induction from leaves and internodes TDZ was preferred over BA in our experiments. Regarding remarkable effect of TDZ in shoot bud induction our results are in concordance with Gercheva et al., 2000; Dobranszki et al., 2002; Qin et al., 2002; Ou et al., 2008.
Fundamentally, the transfer of bacterial T-DNA [positioned on its tumor-inducing ( $\mathrm{Ti})$ plasmid] into the plant nuclear genome is plant genetic transformation. For many fruit species Agrobacterium mediated transformation relies chiefly upon the type of genotype. Conversely to all other strains, A. tumefaciens LBA4404 strain could be adequately removed off from apple explants post co-cultivation with low amounts of antibiotics (Komori et al., 2009; Modgil \& Sharma 2009).

Attributes of antibiotics like vast dimension for bacterial infection and low eukaryotic toxicity allows the widespread use of cefotaxime and carbenicillin to eliminate A. tumefaciens from plant cultures after co-cultivation. Findings of present study are coherent with Modgil \& Sharma (2009) regarding remarkable effect of cefotaxime on bacterial growth elimination (@ $500 \mathrm{mg} \mathrm{l}^{-}$ ${ }^{1}$ ) and its prompt response towards shoot regeneration (@ 200-300 $\mathrm{mg} \mathrm{l}^{-1}$ ). The most significant step in any transformation procedure 
is the discrimination of transformed regenerants from non transformed ones. Miki \& McHugh (2004) reported broad spectrum activity of hygromycin against prokaryotes and eukaryotes and toxicity in plants. Nevertheless, the screening for transgenic regenerated shoots is often partial and difficult due to regeneration of escapes and chimeras. In this study $5 \mathrm{mg} \mathrm{l}^{-1}$ hygromycin was used as a selection pressure for the co-cultivated explants which strengthened the previous findings (Kumar et al., 2004; Modgil \& Sharma 2009, Sharma et al., 2012).

Pre-treatment allows the conditioning of the explants prior to $A$. tumefaciens infection which particularly improves the porosity of cell walls thereby enhancing the transformation rate (Gill et al., 2004). Further, it was reported that 15 minutes Agrobacterium cell suspension infection of explants is quite productive. On the contrary, many reports showed that the infection time and temperature are genotype dependent, while gentle shaking of leaves for different durations at room temperature was preferred to obtain maximum transformation efficiency in $M$. domestica $\mathrm{cv}$. 'Jonagold' and rootstock MM106 respectively (De Bondt et al., 1994; Sharma et al., 2012).

Developed organogenesis protocols or regeneration systems are the backbone of competent genetic transformation methods. Presence of escapes (non-transformed tissues) in this studies is consistent with Radchuck \& Korkhovoy 2005; Flachowsky et al., 2008; Sharma et al., 2012 in case of apple. Usually, the participation of few cells in the origin of new adventitious shoots enhances the likelihood of chimera development (George et al., 2008). Among the developed putative transformed regenerants, few can be chimeras i.e. a mix of transformed and nontransformed cells in the tissues (Hanke et al., 2007). In most transformation systems, the generation of a number of escapes is expected. Regeneration of escapes and chimerical shoots at high frequencies has been reported in some species, although their importance and frequency have been underestimated. The problem of chimerism seems to be more frequent than originally thought and it has been reported in several herbaceous species and woody fruit trees (Padilla \& Burgos, 2010).

Though the adventitious shoot regeneration from wounded leaf segments was reported by Norelli et al., 1996 and Sharma et al., 2012, however, a proficient system of transgenic shoots production via apical internodal explants from etiolated 'Royal Gala' apple shoots was cited by Liu et al., 1998.

PCR has many potentialities in the various fields of biology. Among these, it is one of the diagnostic tool for transformed cells detection. Likewise, in the present investigations the presence of rice chitinase gene (chill) in transformed plants was confirmed by amplifying $584 \mathrm{bp}$ and $237 \mathrm{bp}$ size fragments through PCR as previously reported by Ganeshan et al., 2009; Sharma et al., 2012 who also used the same construct in case of cotton and apple rootstock 'MM106' respectively.

Though the genetic transformation efficiency is significantly lower in present study but first time it helps in developing a simple and reliable chitinase gene transfer protocol for the apple rootstock M7 by using A. tumefaciens. For the improvement of existing trusted rootstocks, transgenic technology can be applied by incorporating the useful foreign genes of interest. Further studies are required for the validation of transgene performance towards resistance to white root rot (Dematophora necatrix) in apple rootstock M7. The results obtained from this research would contribute for possible development of fungal resistant transgenic lines.

\section{Conflict of Interest}

Authors would hereby like to declare that there is no conflict of interest that could possibly arise.

\section{Acknowledgements}

Authors are thankful to the Department of Biotechnology, New Delhi, Government of India for providing financial assistance during the course of the investigation.

\section{References}

Akdemir H, Gago J, Gallego PP, Ciftci YO (2012) Recent advances in fruit species transformation. In: Ciftci YO (Ed.) Transgenic plants-advances and limitations, In Tech, Rijeka, Croatia, Pp 27-62

Bolar JP, Norelli JL, Wong KW, Hayes CK, Herman GE, Aldwinckle HS (2000) Expression of endochitinase from Trichoderma harzianum in transgenic apple increases resistance to apple scab and reduces vigor. Phytopathology 90:72-77

Datta K, Velazhahan R, Oliva N, Ona I, Mew T, Khush G, Muthukrishnan S, Datta S (1999) Over-expression of the cloned rice thaumatin-like protein (PR-5) gene in transgenic rice plants enhances environmental friendly resistance to Rhizoctonia solani causing sheath blight disease. Theoretical and Applied Genetics 98:1138-1145

De-Bondt AD, Eggermont K, Druart P, Vil MD, Goderis I, Vanderleyden J, Broekaert UF (1994) Agrobacterium-mediated transformation of apple (Malus $\mathrm{x}$ domestica Borkh.): an assessment of factors affecting gene transfer efficiency during early transformation steps. Plant Cell Reports 13:587-593

Dobranszki J, Magyar TK, Jambor BF, Kiss E, Lazanyi J, Buban $\mathrm{T}$ (2002) Effect of conditioning apple shoots with meta-topolin on 
the morphogenic activity of in vitro leaves. Acta Agronomica Hungarica 50:117-126

Flachowsky H, Riedel M, Reim S, Hanke V (2008) Evaluation of the uniformity and stability of T-DNA integration and gene expression in transgenic apple plants. Electronic Journal of Biotechnology 11:1-15

Ganeshan M, Bhanumathi P, Kumari KG, Prabha AL, Song PS, Jayabalan N (2009) Transgenic Indian cotton (Gossypium hirsutum) harbouring rice chitinase gene (ChilI) confers resistance to two fungal pathogens. American Journal of Biochemistry and Biotechnology 5: 63-74

George EF, Hall MA, De Klerk GJ (2008) Adventitious regeneration. In George EF, Hall MA, De Klerk GJ (Eds.). Plant propagation by tissue culture (3rd edn)., Springer, Dordrecht, Netherlands, Pp 355-401

Gercheva P, Andinova T, Ivanova K (2000) Plant regeneration from leaf tissues of apple cultivars Granny Smith, Morspur Golden and Starkrimson. Bulgarian Journal of Agricultural Science 6 :637-643

Gill MIS, Singh Z, Agrez V (2004) Factors affecting Agrobacterium-mediated genetic transformation in fruit and nut crops - an overview. Journal of Food Agriculture and Environment 2 : 327-347

Hanke MV, Reidel M, Reim S, Flachowsky H (2007) Analysis of tissue uniformity in transgenic apple plants. Acta Horticulturae 738:301-306

Harris SA, Robinson JP, Juniper BE (2002) Genetic clues to the origin of the apple. Trends in Genetics 18: 426-430

Igarashi M, Hatsuyama Y, Harada T, Akada TF (2016) Biotechnology and apple breeding in Japan. Breeding Science 66: 18-33

Komori S, Watanabe M, Tanaka N, Suzuki A, Wada M, Soejima J, Matsumoto S, Adachi Y, Jun LJ (2009) Antibiotics for Agrobacterium elimination in apple transformation. Horticultural Research 8:419-426

Kumar SM, Kumar BK, Sharma KK, Devi P (2004) Genetic transformation of pigeonpea with rice chitinase gene. Plant Breeding 123: 485-489

Liu Q, Salih S, Hammerschlag F (1998) Etiolation of Royal Gala apple (Malus domestica Borkh.) shoots promoters high-frequency shoot organogenesis and enhanced $\beta$-glucuronidase expression from stem internodes. Plant Cell Reports 18:32-36

Miki B, McHugh S (2004) Selectable marker genes in transgenic plants: applications, alternatives and biosafety. Journal of Biotechnology 107:193-232

Modgil M, Sharma R (2009) Effect of antibiotics on regeneration and to eliminate bacteria during gene transfer in apple. Acta Horticulturae 839:353-360

Murashige T, Skoog F (1962) A revised medium for rapid growth and bioassays with tobacco tissue culture. Physiologia Plantarum $15: 473-497$

Norelli J, Mills JA, Aldwinckle H (1996) Leaf wounding increases efficiency of Agrobacterium-mediated transformation of apple. HortScience 31:1026-1027

Ou CQ, Li LG, He P, Zhang ZH (2008) In vitro adventitious shoot regeneration and induction of tetraploid from leaves of Hanfu apple. Journal of Fruit Science 25:293-297

Padilla IMG, Burgos L (2010) Aminoglycoside antibiotics: structure, functions and effects on in vitro plant culture and genetic transformation protocols. Plant Cell Reports 29:1203-1213

Polanco V, Paredes M, Becerra V Pérez E (2010) Advances in apple transformation technology to confer resistance to fungal diseases in apple crops: a chilean perspective. Chilean Journal of Agricultural Research 70 :297-308

Qin L, Li M, Wong YX, Han LX, Huang ZG, Zhao GR (2002) Effects of different cytokinins on leaves in vitro regeneration of Fuji apple variety. Journal of Fruit Science 19:215-218

Radchuk VV, Korkhovoy VK (2005) The rol B gene promotes rooting in vitro and increases fresh root weight in vivo of transformed apple scion cultivar 'Florina'. Plant Cell Tissue and Organ Culture 81:203-212

Rao AQ, Bakhsh A, Kiani S, Shahzad K, Shahid AA, Hussain T, Riazuddin S (2009) The myth of plant transformation. Biotechnology Advances 27:753-763

Sharma R, Modgil M, Sharma P, Saini, U (2012) Agrobcteriummediated transfer of chitinase gene in apple (Malus $x$ domestica Borkh.) rootstock MM106. Indian Journal of Horticulture 69:1-6

Wong KW, Herman GE, Norelli JL, Gustafson HL, Aldwinckle HS (1999) Chitinase-transgenic lines of 'Royal Gala' apple showing enhanced resistance to apple scab. Acta Horticulturae 484:596-599 